\title{
Exploring Undergraduate Students' Online Interaction in Academic Reading Classroom via WhatsApp Application
}

\author{
Ida Yulianawati \\ Wiralodra University \\ ida.yulianawati@unwir.ac.id \\ Natalia Anggrarini \\ Wiralodra University \\ natalia.anggrarini@unwir.ac.id \\ Anes Nurul Bahari \\ Wiralodra University \\ anesnurulb@gmail.com
}

\begin{abstract}
This research aimed to discuss the potential of the WhatsApp application as a tool of online learning at a higher educational level that could stimulate students' interactions and discussion with the lecturer or their peers. With interactions, they can experience and develop an awareness of behaviors required to facilitate their participation in online learning. Therefore, this study identified the specific and general types of undergraduate students' online interactions and investigated their pattern across time. The study was carried out by 6 undergraduate students of 2019/2020 academic year in the English Education Department, Wiralodra University. Students' posts in WhatsApp group discussion were analyzed in terms of online interaction types identified by MacKinnon (2000) and Jung, et al (2002). The result shows that the students mostly expressed their opinions and judgments in academic-related discussions rather than moved to a higher level of knowledge construction, such as providing their own example upon their ideas and elaborating more on certain topics in the discussion. Further investigation can be done to find out the factors that affect students' interaction, the relationship between topics and online interactions in another online learning platform.
\end{abstract}

Keywords: online learning, online interaction, whatsapp application, academic reading

\section{A. Introduction}

Since coinciding with the pandemic Covid-19 in Indonesia, the teaching English and learning process has changed from face-to-face to online learning. Mulyanti et al., (2020) asserted that Indonesian Minister of Education and Culture has supported the regulations in March 2020, by deactivating educational activities from early age education to higher education and replacing conventional learning method into E-learning. Mather \& Sarkans (2018) stated that the implementation of 
Jadila: Journal of Development and Innovation

E-ISSN: 2723-6900

in Language and Literature Education

P-ISSN: 2745-9578

Publisher: Yayasan Karinosseff Muda Indonesia

Volume. 1 Number 2,2021

Page: $1-18$

E-learning in English language learning has developed some positive impacts, such as flexibility of time and place, extensive learning resources. It helps students become more independent and responsible in gaining knowledge as students are expected to be involved in the learning. Moreover, success or failure in online learning environments has something to do with natural interactions during online learning $(\mathrm{Tu}, 2000)$.

Online teaching and learning in the EFL context can be very personalized when the activities between the teacher and students are interactive. It is supported by Studies (2017), in English language process, the interaction and communication between the students and their environment is needed because it an imperative element to represent the language. With interactions, they can experience and develop an awareness of behaviors required to facilitate their participation in online learning. However, the students may find out challenges to participate in the discussion; for instance, lack of knowledge, communication styles, reluctance the criticize, fear of criticizing, and confusion of feedback (Rovai, 2002).

The use of the social-networking application, such as Google Classroom, Edmodo, Zoom Meeting, Blog, WhatsApp, and so on in teaching and learning, expected students to foster participation in online learning experiences during the pandemic. WhatsApp is one of the alternative tools as a media of online learning. WhatsApp is chosen as an appropriate application in online learning by the characteristics of usefulness and its practicality in teaching and learning that is expected to provide an easy way for the students to interact (Anggrarini \& Wati, 2019). Cohavi as cited by Bouhnik \& Deshen (2014) stated that one of the great features of WhatsApp is its ability to facilitate communication in group discussion, where it can be used as forum discussion during online learning. He also added that the WhatsApp feature provides successful online learning because WhatsApp provides an opportunity for students to talk more about their ideas and be active in the discussion.

In terms of online learning, some previous studies have disussed the use of WhatsApp in the English teaching and learning process. Alshammari, et al., (2017) 
Jadila: Journal of Development and Innovation

E-ISSN: 2723-6900

in Language and Literature Education

P-ISSN: 2745-9578

Publisher: Yayasan Karinosseff Muda Indonesia

Volume. 1 Number 2,2021

Page: $1-18$

found that WhatsApp is a practical mobile application to support foreign language learning. Minalla (2018) reported that the participants who received the voice messages on WhatsApp treatment significantly outperformed those who received text messages on WhatsApp. While, Mazana (2018) reported that WhatsApp was used for sharing material, assignment. In her study, she also found that WhatsApp can enhance the interactions between teachers and students.

Those previous studies did not explore the types of student interaction that occurred during the online learning process. Thus, this study explored online interactions and their pattern across time during the learning process using WhatsApp application. This study focused on the synchronous interaction in distance education based on Bates (1995) and the theory from MacKinnon (2000) and Jung et al., (2002) to analyzed undergraduate students' types of online interactions using WhatsApp application.

\section{B. Research Methodology}

This qualitative research employed a case study design to meet the purpose of the research. The nature of the study is targeted to identify the categories of students' online interaction and describes its patterns of online interaction used by the students. The participants of this study were 6 students who took Academic Reading subject from the fourth semester of undergraduate English students of Wiralodra University, Indramayu. The process of determining participants was carried out by grouping students by their awareness of interaction. They were grouped into three groups of students; high, moderate, and low scores. From those groups of students, the writer found the students' similar types of online interactions. In other words, the writer found a pattern of interaction that was repeated many times from the three groups of students. Therefore, the writer decided to limit the number of participants from each group. The writer only took 2 students from each group as representatives.

To get richer data, all messages posted by undergraduate students on WhatsApp group discussion during online learning were captured and printed out 
Jadila: Journal of Development and Innovation

E-ISSN: 2723-6900

in Language and Literature Education

P-ISSN: 2745-9578

Publisher: Yayasan Karinosseff Muda Indonesia

Volume. 1 Number 2,2021

Page: $1-18$

as a document to make it easier for the writer to identify their types of interaction. Then it was classified into MacKinnon (2000) and Jung et al., (2002) theories. After the categories were defined, the messages assigned to the relevant categories and their frequencies were counted.

\section{Result and Discussion}

\section{Result}

\section{Undergraduate Students' Specific Types of Online Interaction via WhatsApp Application}

From 10 types of online interactions based on MacKinnon (2000), this study found 9 types of specific online interaction in Academic Reading course. The total messages of 6 participants are 123 messages or responses. The following table represents a sample of interaction: the comments or responses posted by the undergraduate students in WhatsApp group discussion.

Table 1. Sample of Undergraduate Students' Comments and their Specific Types of

Online Interaction

\begin{tabular}{|l|l|c|}
\hline \multicolumn{1}{|c|}{$\begin{array}{c}\text { Types of } \\
\text { Interactions }\end{array}$} & \multicolumn{1}{|c|}{ Sample of Interactions } & Code \\
\hline $\begin{array}{l}\text { Acknowledgment } \\
\text { of Opinion }\end{array}$ & $\begin{array}{l}\text { "In my opinion, an empirical review is the type of } \\
\text { that literature review because it comprises the } \\
\text { previous study." }\end{array}$ & A $1-2^{\text {nd }}$ meeting)
\end{tabular}




\begin{tabular}{|c|c|c|}
\hline & $\begin{array}{l}\text { in a different situation. The author argued that } \\
\text { interaction between student-teacher and teacher } \\
\text { mentor or educator does not show as learning to be } \\
\text { professional and many students teacher try to exist in } \\
\text { that interaction." } \\
\qquad\left(\mathrm{S} 1-1^{\text {th }} \text { meeting) }\right.\end{array}$ & \\
\hline $\begin{array}{l}\text { Example to idea } \\
\text { (induction, } \\
\text { conclusion) }\end{array}$ & $\begin{array}{l}\text { "In this meeting today, we can conclude that } \\
\text { methodology is a big part of a research which tells } \\
\text { about the process not only the research design but } \\
\text { also context of research, participants and so on. The } \\
\text { author should talk about research design, the context } \\
\text { of research, participants, data collection, and data } \\
\text { analysis. The research methodology and research } \\
\text { design is different. Research design is more specific } \\
\text { while methodology tells a whole process of } \\
\text { research." } \\
\left(\mathrm{S} 3-3^{\text {rd }} \text { meeting) }\right.\end{array}$ & E2I \\
\hline $\begin{array}{l}\text { Clarification, } \\
\text { elaboration } \\
\text { (reiterating, } \\
\text { building on } \\
\text { point) }\end{array}$ & $\begin{array}{l}\text { "Literature review is important because to integrate } \\
\text { and conclude things that are known in the area of } \\
\text { research. Before presenting the literature, the author } \\
\text { must select various research or journals relevant to } \\
\text { the research he is likely to do. Furthermore, } \\
\text { researchers can also evaluate the literature that will } \\
\text { be examined. After organizing and evaluating, } \\
\text { researchers can conduct analysis and synthesis." } \\
\text { (S2-2 }{ }^{\text {nd }} \text { meeting) }\end{array}$ & CLE \\
\hline $\begin{array}{l}\text { Idea to example } \\
\text { (deduction, } \\
\text { analogy) }\end{array}$ & $\begin{array}{l}\text { "Got it, sir. So the research that you are doing now is } \\
\text { one example of narrative inquiry, right?" } \\
\text { (S2-4 } 4^{\text {th }} \text { meeting) }\end{array}$ & $\mathrm{I} 2 \mathrm{E}$ \\
\hline
\end{tabular}


Jadila: Journal of Development and Innovation

E-ISSN: 2723-6900

in Language and Literature Education

P-ISSN: 2745-9578

Publisher: Yayasan Karinosseff Muda Indonesia

Volume. 1 Number 2,2021

Page: 1-18

\begin{tabular}{|c|c|c|}
\hline $\begin{array}{l}\text { Contrast } \\
\text { (distinction, } \\
\text { discrimination) }\end{array}$ & $\begin{array}{l}\text { "Definition is a limit or meaning, can also be } \\
\text { interpreted words, phrases, or sentences that express } \\
\text { the meaning, description, or the main characteristics } \\
\text { of people, objects, processes, or activities. At the } \\
\text { same time, a report is a form of delivery of news, } \\
\text { information, notification, or accountability. That is } \\
\text { why the author cannot mention defining in the } \\
\text { reported." } \\
\left(\mathrm{S} 2-2^{\text {nd }} \text { meeting) }\right.\end{array}$ & $\mathrm{CN}$ \\
\hline $\begin{array}{l}\text { Off topic/faulty } \\
\text { reasoning (entry } \\
\text { inappropriate) }\end{array}$ & "Sorry, sir. Baru bangun." & OT \\
\hline $\begin{array}{l}\text { Compare } \\
\text { (similarity, } \\
\text { analogy) }\end{array}$ & $\begin{array}{l}\text { "I think so, and it implies that if the teaching } \\
\text { practicum involves teaching emotion both the student } \\
\text { teacher and their mentor." } \\
\text { (S2-2 } 2^{\text {nd }} \text { meeting) }\end{array}$ & $\mathrm{CM}$ \\
\hline
\end{tabular}

Following that, undergraduate students' types of online interaction were analyzed by calculating the frequency of each type of interactions performed by the students in WhatsApp group discussion. The detail finding based on the result of the higher to the lower types of interaction is presented in the table as follow:

Table 2. Analysis of Undergraduate Students' Specific Types of Online Interaction

\begin{tabular}{|c|c|c|c|c|c|c|c|c|c|c|c|}
\hline Student & A & Q & EV & E2I & CLE & I2E & CN & OT & CM & CE & Total \\
\hline S1 & 11 & 8 & 1 & 1 & 3 & 1 & 2 & 1 & 0 & 0 & 28 \\
\hline S2 & 25 & 12 & 4 & 2 & 3 & 4 & 1 & 0 & 1 & 0 & 52 \\
\hline S3 & 14 & 2 & 2 & 2 & 0 & 0 & 0 & 0 & 0 & 0 & 20 \\
\hline S4 & 7 & 4 & 0 & 2 & 0 & 0 & 0 & 0 & 0 & 0 & 13 \\
\hline S5 & 5 & 0 & 0 & 0 & 0 & 0 & 0 & 0 & 0 & 0 & 5 \\
\hline S6 & 4 & 0 & 0 & 0 & 0 & 0 & 0 & 1 & 0 & 0 & 5 \\
\hline Total & $\mathbf{6 6}$ & $\mathbf{2 6}$ & $\mathbf{7}$ & $\mathbf{7}$ & $\mathbf{6}$ & $\mathbf{5}$ & $\mathbf{3}$ & $\mathbf{2}$ & $\mathbf{1}$ & $\mathbf{0}$ & $\mathbf{1 2 3}$ \\
\hline
\end{tabular}


The result above was quite various since the students had different abilities to participate in the discussion. It was found 9 of 10 specific types of online interaction with 123 interactions from 6 students in ten meetings of the study. Overall, Acknowledgement of Opinions (A) dominated this study, which achieved 66 interactions. Besides, Cause and Effect (CE) category was not found in this study. It means that almost all students had tried to think critically to gives their opinions and automatically active to participate in the discussion, but indicated lacking in provide the cause and effect of the ideas. The frequency of online interactions performed by students gave the influence in the result of the learning. In this case, the higher online interaction performed by S2 with a total of 52 interactions and dominated Acknowledgement of Opinion (A). While the lowest one was only 5 interactions. The result showed that online interaction indicated the students with the highest scores dominate active participation in the discussion. When students' interaction is recognized in the classroom, a positive learning atmosphere and student exchange of information also foster educational success.

\section{Undergraduate Students' General Types of Online Interaction via WhatsApp Application}

To identify the general types of interaction, the writer used the theory of Jung et al (2002), which included academic/instructional interaction, collaborative interaction, and interpersonal/social interaction. The sample of online interaction in general types presented in the table below:

Table 3. Sample of Undergraduate Students' Comments and their General Types of Online Interaction

\begin{tabular}{|c|c|c|}
\hline Types of Interactions & Sample of Interactions & Code \\
\hline Academic/Instructional & $\begin{array}{c}\text { "Narrative inquiry is more than just using a } \\
\text { narrative or story approach to data collection. } \\
\text { It involves listening, viewing and interpreting } \\
\text { narratives in particular ways, one key defining } \\
\text { feature is the intent to invite stories meaning }\end{array}$ & \\
\hline
\end{tabular}




\begin{tabular}{|l|l|c|}
\hline & $\begin{array}{l}\text { that the interviewee is positioned as a } \\
\text { narrator." }\end{array}$ & $\left(\mathrm{S} 6-4^{\text {th }}\right.$ meeting $)$ \\
\hline Collaborative & $\begin{array}{l}\text { "I think so, and it implies that if the teaching } \\
\text { practicum involves teaching emotion both } \\
\text { student teacher and their mentor." } \\
\left(\text { S2- } 1^{\text {th }} \text { meeting }\right)\end{array}$ & C \\
\hline Interpersonal & $\begin{array}{l}\text { "Thank you for your explain of the material } \\
\text { today, sir." }\end{array}$ & I \\
$\left(\mathrm{S} 3-5^{\text {th }}\right.$ meeting $)$ & \\
\hline
\end{tabular}

According to the result above, the three general types of online interaction found in this study, they included Academic/Instructional (A/I), Collaborative (C), and Interpersonal (I) interactions. It means that the students' interaction was quite active during the discussion either in academic, collaborative, or interpersonal interactions. The frequency of each category will be elaborated in this following table:

Table 6. Analysis of Undergraduate Students' General Types of Online Interaction

\begin{tabular}{|c|c|c|c|c|}
\hline Student & A/I & C & I & Total \\
\hline S1 & 26 & 1 & 6 & 33 \\
\hline S2 & 41 & 8 & 14 & 63 \\
\hline S3 & 17 & 1 & 3 & 21 \\
\hline S4 & 11 & 2 & 4 & 17 \\
\hline S5 & 2 & 3 & 0 & 5 \\
\hline S6 & 2 & 2 & 1 & 5 \\
\hline Total & $\mathbf{1 0 3}$ & $\mathbf{1 7}$ & $\mathbf{2 4}$ & $\mathbf{1 4 4}$ \\
\hline
\end{tabular}

According to the table analysis above, there were 144 interactions belonged to general types from all participants. Following that, the students were generally performed the Academic/Instructional (A/I) category, with 103 interactions. In other words, the students give responses toward the materials that given by the lecturer. According to Jung et al., (2002), the academic/instructional category 
Jadila: Journal of Development and Innovation

E-ISSN: 2723-6900

in Language and Literature Education

P-ISSN: 2745-9578

Publisher: Yayasan Karinosseff Muda Indonesia

Volume. 1 Number 2,2021

Page: $1-18$

always occurs when the student reads online materials, gets task-oriented feedback from the lecturer or more competent peers, or participates in task-oriented learning activities.

In this study, the most frequent interactions were performed by $\mathrm{S} 2$ with the total of 63 comments or interactions during online discussion and dominate the Academic/Instructional (A/I) interaction. While S5 and S6 performed the least interactions. Both of them only performed 5 interactions. In this case, S5 and S6 indicated afraid to give their opinion individually, tend to be passive when the lecturer provides the questions. Sometimes, they feel the topics challenging to comprehend, so they tend to be silent. When the lecturer asks to work as a team, they were quite active in the discussion. It showed by the frequency of their Collaborative $(\mathrm{C})$ category was quite high. It means that the lowest students seem to be active when there were encouragement and cooperation thoughts from their group mates.

\section{Undergraduate Students' Types of Online Interaction across Time}

Undergraduate students' types of online interaction were measured according to its frequencies or numbers of messages posted by 6 students in WhatsApp group discussion and each week topics. Each percentage of specific types of online interaction were described and shown in figure 1.

Figure 1. Graph of Undergraduate Students' Specific Types of Online Interaction across Time

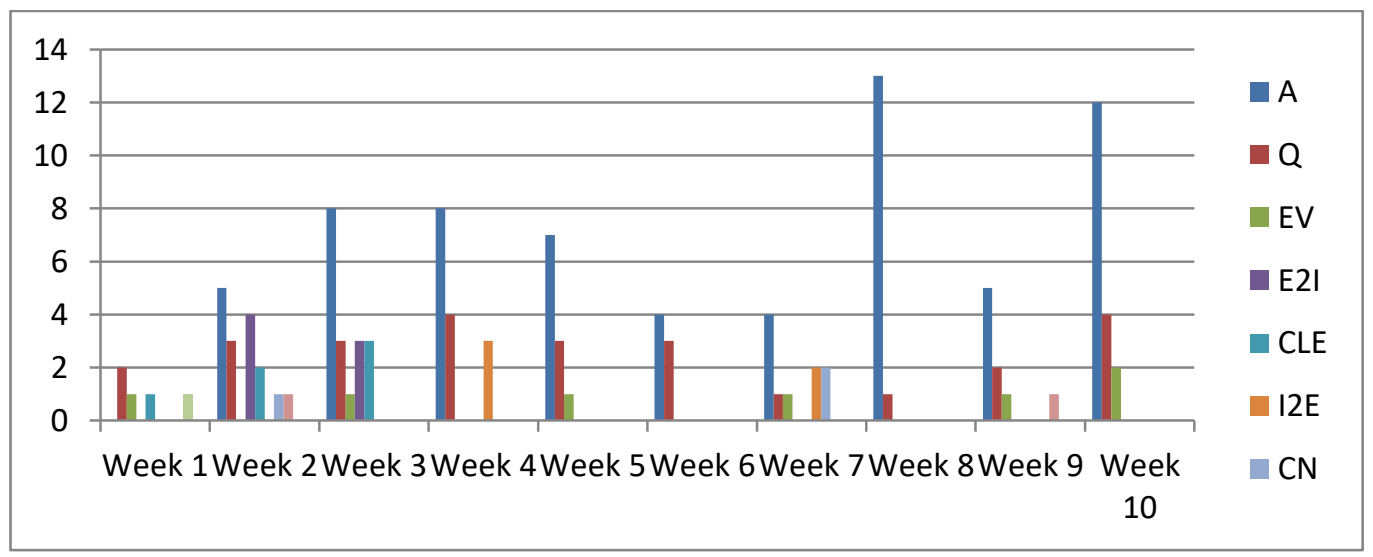


The figure above shows that students' interaction unstable every week. In all of the week, the lowest percentage showed in week 1. It may because this week is the first impression for them to conduct online learning via WhatsApp application. Yoon (2003) stated that online learning environments, especially technology-mediated interactions, were relatively new and challenging from time and place dependent face-to-face interactions. It can be said that students had no previous experience in online learning, it caused unstable interactions in every week. From figure 1, it is seen that the Acknowledgement of Opinion category dominated the result, and mainly occurred in week 8 . Then, followed by Question category occurred in week 4 and week 10 were achieved rates 4 interactions. Even though, both categories also unstable in each week. It depended on the discussion of the topic every week. Nevertheless, so far, the students show improvement in their Acknowledgement of Opinion and Question interactions. For instance, Acknowledgement of Opinion even did not occurred in week 1 then there were a significant increased until week 4. It means that students has been shows their response actively during those weeks. Likewise, Question category consistently increased start from week 1 until week 6. Although in week 7 and week 8 they show a significant decrease. Indeed, the ups and downs of students' interactions also occur in the general types. The following presented the figure of undergraduate students' online interactions in general types across time.

Figure 2. Graph of Undergraduate Students' General Types of Online Interaction across Time 


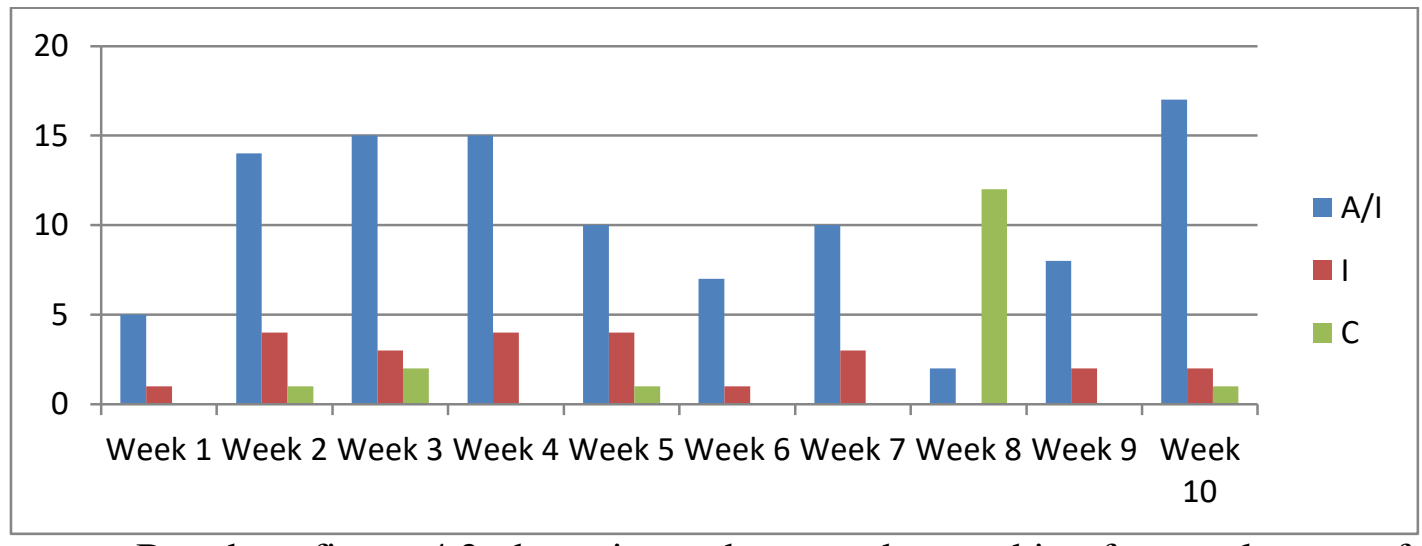

Based on figure 4.2 above it can be seen the graphic of general types of online interactions in details. It shows the unstable interactions in each week, either Academic/Instructional, Interpersonal, or Collaborative categories. However, it was dominated Academic/Instructional category that showed high percentages in each week; especially in week 10 achieved 17 interactions. Following that, Interpersonal category was almost occurred in every week, and it was stable. The students were able give their expressions in social interactions, such as greeting when the discussion is started and peer feedback or social feedback during the discussion or at the end of the discussion. In contrast, the unstable interactions showed by the Collaborative category. Even though, according to Agostinho et al., (1997), collaborative interaction provides the students with the opportunity to discuss, argue, negotiate, and reflect upon their existing beliefs and knowledge. Whereas based on figure 4.2 , the Collaborative category only dominated in week 8 . In other weeks, it was only appeared in half of ten weeks, such as in week 2 , week 3 , week 5 , week 8 , and week 10 . Therefore, it can be said that the students not engaged collaboratively with each other in 5 weeks others.

\section{Discussion}

Some kinds of lecturer's comments sometimes encourage the students to provide response, and sometimes to let others notice the talking about the students, then sometimes it encourages others to contribute. Therefore, the students were motivated to be active in the discussion by asking their opinions, asking questions, and even working together with their peers to get the solution. In other words, the Acknowledgement of Opinion (A) and Academic/Instructional (A/I) category was 
Jadila: Journal of Development and Innovation

E-ISSN: 2723-6900

in Language and Literature Education

P-ISSN: 2745-9578

Publisher: Yayasan Karinosseff Muda Indonesia

Volume. 1 Number 2,2021

Page: $1-18$

content-centered and tended to connect with students-content interaction. The interactions were about the ideas or questions directly or related to the course content and assignment. The lecturers expected these kinds of interactions in the discussion. The course was students-content oriented by design, and the students were expected to improve their understanding of various topics through synchronous discussion with their peers and their instructors.

Additionally, in fact that there were more students posit the Question (Q) type throughout the discussion with a total of 26 interactions, Evaluation or Judgment (EV) and Example to Idea (E2I) with a total 7 interactions towards their progress in online discussion. It means that they represent well their opinion, proposed critical questions to the lecturer regarding the materials, and using their judgment over the questions or statements prompted by the lecturer. However, the students show lacking in providing appropriate example upon their ideas. Following that, the students considered least number on certain specific types of online interaction, such as Clarification \& Elaboration (CLE), Idea to Example (I2E), Contrast (CN), and Compare $(\mathrm{CM})$. There were only 6 interactions recorded for students who generated CLE throughout ten meetings of discussion; even Cause and Effect (CE) was not found in this study.

On the other hand, students indicated lacking in providing the example to the real-life (I2E) and provide distinction or differences $(\mathrm{CN})$. As mentioned earlier, another least specific type of online interaction coded in this study is CM. It was only 1 interaction had been categorized as $\mathrm{CM}$ throughout the discussion. It can be said that the most students found difficulties to compare the similarity or explaining the relationship between lecturer's ideas or peer's ideas with their own ideas. This finding is not in line with previous finding that revealed that most students posed example-to-idea, clarification, and idea-to-example types of online interaction (Topcu \& Ubuz, 2008). Whereas, it was expected that students would have deepened the existing discussion by used cause-and-effect, compare or contrast, and provide their idea to example. However, the students used various types of 
Jadila: Journal of Development and Innovation

E-ISSN: 2723-6900

in Language and Literature Education

P-ISSN: 2745-9578

Publisher: Yayasan Karinosseff Muda Indonesia

Volume. 1 Number 2,2021

Page: $1-18$

online interaction here just for drawing their experiences, referring the materials, and completely new information for discussion.

The students also choose to respond to the interactions when some sort the content produced some sort of emotion or personal connection They respond to the interactions that have in some way triggered an emotional response. These responses are often positive ones, such as gratefulness for an explanation suggested by the lecturer or another student. In this study, it was revealed the Interpersonal (I) category occurred especially when students got emotional or social feedback from their peers or teacher were in the form of interpersonal (Jung et al., 2002). In addition, although the activity was in a group, but in this study Collaborative (C) category was rarely occurred. On the other hand, all participants indicated active as individually and lacking in collaboration with their peers. The data shows each student did not perform collaborative interaction at least more than 20 times. It was in line with the result of Quiroz (2008) that found the most interaction throughout individuality rather than collaboration with their peers.

Based on data findings, online interactions were dominated by students with the highest scores. They indicated found the ways how to engage and maintenances the interactions during the discussion. It was because they were used various types of online interaction rather than the others. Then, the students with moderate scores indicated active participation in the discussion when they got the lecturer or their peers, such as their active participation claimed as the attendance by the lecturer and they work together with their peers to solve the problems. In contrast, the students from the lowest scores indicated not active to involve in the discussion. They seem difficult to comprehend the materials and afraid to talk more about their ideas individually. Finally, most of them were considered passive in joined the class and pretended to keep silent. Their frequency of each type showed it was lowest. It may both of them less-confidence tend to be passive. They did not respond the questions or present the questions to the lecturer or their peers although they did not understand the materials. Thus, they give less contribution to the online discussion. 
Jadila: Journal of Development and Innovation

E-ISSN: 2723-6900

in Language and Literature Education

P-ISSN: 2745-9578

Publisher: Yayasan Karinosseff Muda Indonesia

Volume. 1 Number 2,2021

Page: $1-18$

However, a lack of interaction that was very few messages or interactions in a discussion should not necessarily be interpreted as a sign of an unsuccessful learning environment. It depends on many factors that affect the frequency of interactions in a discussion; external and internal factors. For factor external, according to Skogs (2015), such as design factors, size of group, the time of discussion is open, the topic and the clarity of instructions from the teachers and whether or not the contributions to the discussion constitute part of the students' grades or not. Besides, there are internal factors of students' participation, it depended on their knowledge, communication styles, the reluctance of criticizing, fear of criticize, and how the way of giving feedback (Rovai, 2002). Therefore, the frequency of students' interaction here was unstable, it depended on the topics of each meeting and depend on their communication abilities.

Moreover, the data finding found that the students' percentages of interactions changed over time. The topic of each meeting and the lecturer's role were the important thing in maintaining the interest and motivation of students to participate active where influenced the ups and down of interactions in the discussion. For instance, in week 1 the most students show the low contribution. This week is the first week they conducted online discussion via WhatsApp group. It seems they need adaptation, as their learning changes from face-to-face to online learning environments. They must understand the material themselves and initiative to find other sources on the internet to increase understanding of the material being taught. Additionally, internet connection and other activities carried out during online learning could impact the variation of the interaction among students. Hence, when these obstacles occur, they could lose focus on understanding and responding to the material.

A couple of weeks later, they showed significant improvement as they improved interactions and became the active week in the discussion between students and lecturer, either specific or general types. It was according to the number of interactions performed by the students on those weeks. It seems that students were excited and interested in identifying the articles that given by the 
Jadila: Journal of Development and Innovation

E-ISSN: 2723-6900

in Language and Literature Education

P-ISSN: 2745-9578

Publisher: Yayasan Karinosseff Muda Indonesia

Volume. 1 Number 2,2021

Page: $1-18$

lecturer. For instance, they could identify the gaps, literature review, methodology, kind of research design, and discussed its text types. The students were involved in the last two weeks, except week 9 also increased. It showed based on the number of interactions performed by the students in those weeks, and they were worked by collaboratively. Which they were showed the highest percentage of Collaboration (C) category achieved 12 interactions. The topics of those weeks, the lecturer give the stimulus to improve the students' interaction throughout the learning rules, such as the students required response to the topics claimed as the attendance. They shared the articles before the discussion was conducted. Thus, in this case, the lecturer gives more time to encourage students to read critically about the article and particularly analyze research gaps. As a result, the students actively engaged in the discussion with shows up their Acknowledgement of Opinion (A) and Academic/Instructional (A/I) categories.

In contrast, some weeks, students seemed to lose their focus and motivation, especially in the middle of weeks. The weeks were considered as an inactive week, where students' involvement and responses showed low in those weeks. According to Balaji \& Chakrabarti (2010) stated that the level of interaction depends on the learning environment (facilitating discourse, reflective thinking, assessment and feedback, and sense of community), learning process (personalization), and learner characteristics (personality and internet efficacy). Even though the lecturer has facilitated the interaction, giving an example, assessment, and feedback during the discussion, the problems still occur. The internet connectivity could affect the intensity of their learning, or the topic could not activate students' prior knowledge and experience. Therefore, it was only few interactions from the students, and their involvement in discussion decrease in those weeks.

Totally, there were ten weeks of discussion throughout WhatsApp group discussion produced 123 interactions in specific types and 144 interactions in general types of online interactions. Based on data finding and discussion, it can be concluded that different types of online interactions triggered by students where most observed Acknowledgement of Opinion (A) occurred in week 8, then it was 
Jadila: Journal of Development and Innovation

E-ISSN: 2723-6900

in Language and Literature Education

P-ISSN: 2745-9578

Publisher: Yayasan Karinosseff Muda Indonesia

Volume. 1 Number 2,2021

Page: $1-18$

dominated by Academic/Instructional category in week 10. In terms of inequity, there was significant difference between the most active and the inactive week. The students' participation in the discussion may lead to low interactivity and directly, resulting in low productivity and low achievement of their learning process. Hence, the instructor here has to choose the topics for discussions that students feel strongly about to promote interaction among students.

\section{Conclusion}

In conclusion, this study revealed that students were more interested in acknowledging opinions rather than comparing the ideas related to the topic. It shows that students prefer to respond to the materials with share their ideas or opinions rather than move to a higher level of knowledge construction, such as providing their own example upon their ideas and elaborating more on certain topics in the discussion. In addition, although the discussion was conducted in WhatsApp group discussion, the students prefer used the Academic/Instructional (A/I) category in general types of online interaction rather than the Collaborative (C) category. It indicated the students active individually and lacking in collaboration with their peers. It was in line with the result of Quiroz (2008) that found the most interaction throughout individuality rather than collaboration with their peers. Sometimes, some factors affect the students' participation in the discussion, such as the topics, their knowledge, internet connection, time of discussion, and the most important thing is motivation.

This study implies the importance of interactions in effective and positive online learning environments. The students need to be motivated and conscious of the importance of interaction during the discussion. When the students are motivated and responsible for the contribution of the interaction, they are most likely to participate spontaneously in the discussion. Although, this study only focuses on students' interactivity with their lecturer or their peers without regard to the unstable students' interaction factors. Furthermore, this study suggests that other researchers investigate other factors that affect students' interaction and 
Jadila: Journal of Development and Innovation

E-ISSN: 2723-6900

in Language and Literature Education

P-ISSN: 2745-9578

Publisher: Yayasan Karinosseff Muda Indonesia

Volume. 1 Number 2,2021

Page: $1-18$

examine the relationship between topics and online interactions in another platform, such as Google Classroom, Google Meet, Zoom Meeting, Email, Blogs, etc.

\section{References}

Agostinho, S., Lefoe, G., \& Hedberg, J. (1997). Online collaboration for learning: a case study of a post graduate university course. Retrieved from http://ausweb.scu.edu.au/proceedings/agostinho/paper.html on July, $3^{\text {rd }} 2020$

Alshammari, R., Parkes, M., \& Adlington, R. (2017). Using WhatsApp in EFL instruction with Saudi Arabian University students. Arab World English Journal (AWEJ). 8(4), 25.

Anggrarini, N \& Wati, A. (2019). Utilizing blog in elt writing to Non-English major undergraduate students of Wiralodra University. Wiralodra English Journal (WEJ). 3(2), 314-328.

Balaji, M. S., \& Chakrabarti, D. (2010). Students' interactions in online discussion forum: empirical research from "Media Richness Theory" Perspective. Journal of Interactive Online Learning, 9(1), 1-23.

Bannan-Ritland, B. (2002). Computer-Mediated Communication, E-learning, and Interactivity: A Review of the Research. The Quarterly Review of Distance Education, 3(2), 161-179

Bates, A. W. (1995). Technology, open learning and distance education. London: Routledge

Bouhnik, D., \& Deshen, M. (2014). WhatsApp goes to school: mobile instant messaging between teachers and students. Journal of Information Technology Education Research. 13(2), 217-231.

Delahunty, J., Verenikina, I., \& Jones, P. (2014). Socio-emotional connections: Identity, belonging and learning in online interactions. A Literature Review. Technology, Pedagogy, and Education, 23 (2), 243-265

Grinager, H. (2006). How education technology leads to improved student achievement. National Conference of State Legislatures, 1-11

Jung, I., Choi, S., Lim, C., \& Leem, J. (2002). Effects of different types of interaction on learning achievement, satisfaction and participation in webbased instruction. Innovations in Education and Teaching International. 39:2, 153-162

Kementerian Pendidikan dan Kebudayaan. (2020). Surat Edaran Mendikbud. Retrieved from https://www.kemdikbud.go.id/main/ on August, $20^{\text {th }} 2020$

Kung-Ming, T., \& Khoon-Seng, S. (2009). Asynchronous vs Synchronous Interaction. Encyclopedia of Distance Learning, Second Edition (122-131)

MacKinnon, G. R. (2000). The dilemma of evaluating electronic discussion group. Journal of Research on Computing in Education, 33(2), 125-131

Mather, M., \& Sarkans, A. (2018). Students perceptions of online and face-to-face learning. International Journal of Curriculum and Instruction, 10(2), 61-76 
Jadila: Journal of Development and Innovation

E-ISSN: 2723-6900

in Language and Literature Education

P-ISSN: 2745-9578

Publisher: Yayasan Karinosseff Muda Indonesia

Volume. 1 Number 2,2021

Page: $1-18$

Mazana, M. Y. (2018). Social media in the classroom: WhatsApp a new communication tool for enhanced class interactions. Business Education Journal (BEJ). 2(1), 3.

Minalla , Amir Abdalla. (2018). The effect of whatsapp chat group in enhancing efl learners' verbal interaction outside classroom contexts. English Language Teaching, 11(3), 3.

Moore, M. G. (1989). Three types of interaction. The American Journal of Distance Education, 3 (2), 1-6

Mulyanti, B., Purnama, W., \& Pawinanto, R. E. (2020). Distance learning in vocational high schools during the covid-19 pandemic in West Java Province, Indonesia. Indonesian Journal of Science and Technology, 5(2), 271-282

Quiroz, J. S. (2008). Teachers' interaction in a virtual learning environment: a comprehensive approach. Interactive Educational Multimedia, University of Barcelona, 1(3), 66-68

Raman, A., Sani, R.M., \& Kaur, P. (2014). Facebook as a collaborative and communication tool: a study of secondary school students in Malaysia. Journal of Social and Behavioral Science, 155 (2014), 141-146

Rich, S. \& Hilbert, K. (2004). Designing an online course for distance education course instructors and authors. Wisconsin: University of Wisconsin

Rovai, A. P. (2002). Building sense of community at a distance. The International Review of Research in Open and Distributed Learning, 3 (1), 2.

Selwyn, N. (2009). Exploring students' education related use of facebook. Learning, Media and Technology. 34 (2), 157-174

Skogs, J. (2015). Language and Interaction in Online Asynchronous Communication in University Level English Courses. (Doctoral dissertation, Karistad University Studies, 2015)

Studies, L. (2017). The impact of vocabulary knowledge on reading, writing, and proficiency scores of efl learners. Dil ve Dilbilimi Calismari Dergisi, 13(1), 352-378

Topcu, A., \& Ubuz, B. (2008). The effects of metacognitive knowledge on the preservice teachers' participation in the asynchronous online forum. Educational Technology \& Society, 11 (3), 1-12

Tu, C. H. (2000). Strategies to increase interaction in online social learning environments. Paper Presented at the Society for Information Technology and Teacher Education International Conference, San Diego, CA

Watts, L. (2016). Synchronous and asynchronous communication in distance learning. Quarterly Review of Distance Education, 17(1), 23-32

Wilson, G. \& Stacey, E. (2004). Online interaction impacts on learning: teaching the teachers to teach online. Australasian Journal of Educational Technology, 20(1), 33-48

Yoon, S. (2003). In search of meaningful online learning experience. New Directions for Adult and Continuing Education, pp. 19-30, 100(4), Wiley Periodicals, Inc

Yuhetty. (2002). ICT and Education in Indonesia. Retrieved from http://gauge.ugakugei.ac.jp/ on July, $10^{\text {th }} 2020$ 